\title{
Secondary organic aerosol formation from isoprene photooxidation during cloud condensation-evaporation cycles
}

\author{
L. Brégonzio-Rozier ${ }^{1}$, C. Giorio ${ }^{2,3}$, F. Siekmann ${ }^{4}$, E. Pangui ${ }^{1}$, S. B. Morales ${ }^{1}$, B. Temime-Roussel ${ }^{4}$, A. Gratien ${ }^{1}$, \\ V. Michoud ${ }^{1}$, M. Cazaunau ${ }^{1}$, H. L. DeWitt ${ }^{4}$, A. Tapparo ${ }^{3}$, A. Monod $^{4}$, and J.-F. Doussin ${ }^{1}$ \\ ${ }^{1}$ Laboratoire Interuniversitaire des Systèmes Atmosphériques (LISA), UMR7583, CNRS, Université Paris-Est-Créteil \\ (UPEC) et Université Paris Diderot (UPD), Institut Pierre Simon Laplace (IPSL), Créteil, France \\ ${ }^{2}$ Department of Chemistry, University of Cambridge, Cambridge CB2 1EW, UK \\ ${ }^{3}$ Dipartimento di Scienze Chimiche, Università degli Studi di Padova, Padova, 35131, Italy \\ ${ }^{4}$ Aix-Marseille Université, CNRS, LCE FRE 3416, 13331, Marseille, France \\ Correspondence to: L. Brégonzio-Rozier (lola.bregonzio@lisa.u-pec.fr) and A. Monod (anne.monod@univ-amu.fr)
}

Received: 21 June 2015 - Published in Atmos. Chem. Phys. Discuss.: 31 July 2015

Revised: 7 December 2015 - Accepted: 6 January 2016 - Published: 15 February 2016

\begin{abstract}
The impact of cloud events on isoprene secondary organic aerosol (SOA) formation has been studied from an isoprene / $\mathrm{NO}_{x}$ / light system in an atmospheric simulation chamber. It was shown that the presence of a liquid water cloud leads to a faster and higher SOA formation than under dry conditions. When a cloud is generated early in the photooxidation reaction, before any SOA formation has occurred, a fast SOA formation is observed with mass yields ranging from 0.002 to 0.004 . These yields are 2 and 4 times higher than those observed under dry conditions. When the cloud is generated at a later photooxidation stage, after isoprene SOA is stabilized at its maximum mass concentration, a rapid increase (by a factor of 2 or higher) of the SOA mass concentration is observed. The SOA chemical composition is influenced by cloud generation: the additional SOA formed during cloud events is composed of both organics and nitrate containing species. This SOA formation can be linked to the dissolution of water soluble volatile organic compounds (VOCs) in the aqueous phase and to further aqueous phase reactions. Cloud-induced SOA formation is experimentally demonstrated in this study, thus highlighting the importance of aqueous multiphase systems in atmospheric SOA formation estimations.
\end{abstract}

\section{Introduction}

Tropospheric fine aerosol particles are known to cause several environmental impacts, including adverse health effects and radiative forcing on climate (Hallquist et al., 2009; IPCC, 2013). Organic compounds contribute a significant percentage (from 20 to $90 \%$ ) of the total submicron aerosol mass and secondary organic aerosol (SOA) accounts for a substantial fraction of this organic mass (Kanakidou et al., 2005; Zhang et al., 2007). SOA formation results from the atmospheric oxidation of volatile organic compounds (VOCs) leading to the formation of less volatile oxidation products that can undergo gas to particle conversion. Some of these oxidized species contain acid, hydroxyl and/or aldehyde functional groups that increase their water solubility, and thus explain their presence in cloud droplets (Herckes et al., 2013; Herrmann et al., 2015). Clouds cover $\sim 70 \%$ of the earth surface on average (Stubenrauch et al., 2013; Wylie et al., 2005) and only $\sim 10 \%$ of them precipitate while the remaining $\sim 90 \%$ dissipate, leading to evaporation of volatile compounds and condensation of lower-volatility species (Herrmann et al., 2015).

In the aqueous phase, soluble organic compounds can react with hydroxyl radicals $(\mathrm{OH})$ and/or by direct photolysis, similar to reactions in the gas phase but in a depleted $\mathrm{NO}_{x}$ environment. Aqueous-phase chemical pathways thus lead to enhanced production of acids, such as oxalic acid, (Carlton et al., 2007, 2006), and oligomers that have been observed 
from the photooxidation of pyruvic acid (Reed Harris et al., 2014), glyoxal (Carlton et al., 2007), methylglyoxal (Lim et al., 2013; Tan et al., 2012), methacrolein (MACR) and methyl vinyl ketone (MVK) (Liu et al., 2012b), and glycolaldehyde (Perri et al., 2009). The produced oligomers and/or humic-like substances (HULIS) are low volatility species and may remain in the particle phase after water evaporation (Ervens et al., 2014; Lim et al., 2013), leading to the formation of new SOA from aqueous phase, called aqSOA (Ervens et al., 2011).

Recent laboratory (Lim et al., 2013; Liu et al., 2012b), field (Dall'Osto et al., 2009; Huang et al., 2006; Lee et al., 2012; Lin et al., 2010; Peltier et al., 2008) and modelling studies (Carlton and Turpin, 2013; Couvidat et al., 2013; Ervens et al., 2008) suggest that this additional SOA formation pathway can be considered important in terms of quantity (up to $+42 \%$ of carbon yields (Ervens et al., 2008)) and composition (Ervens et al., 2011); however, these processes have never been directly experimentally demonstrated.

Indeed, previous experiments from the literature evaluating an SOA source in the aqueous phase were only carried out in homogeneous phases separately. Studies were performed in homogeneous aqueous phases to observe oligomers and low volatility organic acids formation (Altieri et al., 2008; Carlton et al., 2006; Liu et al., 2012b), in homogeneous aqueous phase solutions with nebulization and drying of the solutions to evaluate aqSOA formation (El Haddad et al., 2009; Ortiz-Montalvo et al., 2012), and in the gas phase with SOA (called gasSOA) formation followed by immersion of these gasSOA in homogeneous aqueous phases (Bateman et al., 2011; Liu et al., 2012a). Previous experimental studies have not been performed on a multiphase system and, as a result, they only refer to the amount of precursor consumed in aqueous phase to determine formation yields. Consequently, and contrary to SOA yields obtained in gaseous phase (gasSOA), these yields cannot be directly implemented in multiphase models because the link between aqueous and gaseous phases (transfer between the two phases) is not taken into account. These works thus lead generally to an overestimation of yields associated with gaseous precursors, whose concentrations depend on the relative importance of their loss in the gaseous phase and their transfer in the aqueous phase. Furthermore, Daumit et al. (2014) recently showed that the reactivity in a multiphase system may be substantially different from reactivity in homogeneous aqueous phase, highlighting the need to study controlled multiphase systems, which are more realistic for the atmosphere.

In the present study, taking advantage of the ability to artificially produce clouds in the CESAM simulation chamber (Wang et al., 2011), dedicated multiphase experiments were carried out to study SOA multiphase formation from isoprene in order to experimentally observe and quantify the impact of cloud-phase reactions on SOA formation. Isoprene was chosen as the precursor because it is highly reactive and it represents the most emitted VOC globally. Isoprene gas-phase ox- idation is known to lead to low yields of gasSOA (BrégonzioRozier et al., 2015; Dommen et al., 2006; Edney et al., 2005; Kleindienst et al., 2006; Kroll et al., 2005; Zhang et al., 2011) and to large amounts of volatile water soluble compounds (such as methylglyoxal, glyoxal, glycolaldehyde and pyruvic acid), which can interact with the aqueous phase in the atmosphere and potentially lead to the formation of aqSOA after water evaporation. In this study, the formation of aqSOA from isoprene photooxidation in the presence of clouds is investigated by studying the concentration and chemistry of gaseous, aqueous and particulate phases as well as the chemical exchanges between these phases.

\section{Experimental section}

Experiments were carried out in the CESAM chamber as described in detail by Wang et al. (2011), and BrégonzioRozier et al. (2015). Briefly, it is a $4.2 \mathrm{~m}^{3}$ stainless steel reactor equipped with three xenon arc lamps and Pyrex ${ }^{\circledR}$ filters of $6.5 \mathrm{~mm}$ thickness. During each experiment, the reactive mixture is maintained at a constant temperature with a liquid coolant circulating inside the chamber double wall and monitored by a thermostat (LAUDA, Integral T10000 W). Temperature and relative humidity $(\mathrm{RH})$ are continuously monitored in the chamber using a Vaisala HUMICAP HMP234 probe.

\subsection{Experimental protocols}

\subsubsection{Cloud generation}

To investigate the influence of a cloud on SOA formation, a specific protocol allowing cloud generation with a lifetime close to droplet lifetime in the atmosphere $(\sim 2-30 \mathrm{~min}$, Colvile et al., 1997) in the presence of light was designed. Clouds were generated by adding water vapour into the chamber up to saturation: at $22^{\circ} \mathrm{C}$, ca. $81 \mathrm{~g}$ of water vapour was introduced to reach saturation and to observe cloud formation. The ultrapure water used was obtained fresh from an Elga Stat Maxima Reverse Osmosis Water Purifier system, which includes reverse osmosis, micro-filtration, nucleargrade deionization, activated carbon modules and an irradiation module at $254 \mathrm{~nm}$ leading to a resistivity greater than 18.2 M $\Omega$. As described in detail by Wang et al. (2011), water vapour was pressurized in a small, $5 \mathrm{~L}$, stainless steel vessel located below the chamber. This small reactor was filled halfway with ultrapure water and heated to reach a relative pressure of 1000 mbar. Half-inch stainless steel tubing equipped with a valve was used to connect the vessel to the chamber and allowed water vapour injection near the chamber's fan. Due to the 1000 mbar pressure difference between the small reactor and the chamber, opening the valve induced an instantaneous adiabatic cooling of the water vapour in the chamber. Prior to injection in the chamber, the pressurized reactor was purged at least five times to eliminate any 
residual air. Using this procedure, starting from dry conditions in the chamber $(<5 \% \mathrm{RH})$, the first water vapour injection allowed the chamber to reach $80 \%$ RH within less than $1 \mathrm{~min}$. A second water vapour injection leads to water saturation in the chamber and cloud formation. The obtained clouds were monitored, and Table 1 shows that their mean physical properties were close to those of typical atmospheric clouds. A typical droplet mass size distribution is also shown in Fig. S1 in the Supplement. Using the above described procedure, several clouds could be generated during one experiment (typically 2 or 3 ).

\subsubsection{Cleaning and control experiments}

In order to avoid any contamination from semi-volatile organic compounds (SVOCs) off-gassing from the walls, a manual cleaning of the chamber walls was performed prior each experiment. To this purpose, lint free wipes (SpecWipe $\left.{ }^{\circledR} 3\right)$ soaked in ultrapure water $(18.2 \mathrm{M} \Omega$, ELGA Maxima) were used. To complete this manual cleaning, the walls were heated at $40^{\circ} \mathrm{C}$, and the chamber was pumped down to secondary vacuum in the range of $6 \times 10^{-4}$ mbar for $2 \mathrm{~h}$ at a minimum. After pumping, the chamber was cooled down to $20-22{ }^{\circ} \mathrm{C}$, and a control experiment was performed by generating a cloud in the presence of a $\mathrm{N}_{2} / \mathrm{O}_{2}$ mixture $(80 \% / 20 \%)$, under irradiation. All of the instruments were connected to the chamber during the entire control experiment which lasted for $\sim 1 \mathrm{~h}$ after cloud generation. The aim of these control experiments was to monitor aqSOA formation arising from the dissolution of any remaining water soluble VOCs off-gassing from the walls or from contaminants introduced with water vapour. After this control experiment, the temperature of the chamber walls was increased to $50^{\circ} \mathrm{C}$ before starting overnight pumping. The amount of particulate matter observed during all the control experiments was fairly reproducible with an average value of $1.5 \pm 0.4 \mu \mathrm{g} \mathrm{m}^{-3}$ of dried particles formed during a cloud event (Table S1 in the Supplement).

\subsubsection{Cloud experiments}

Two types of cloud experiments were performed to study the impact of clouds on isoprene-SOA formation: (i) clouds generated during the first stages of isoprene photooxidation, prior any gasSOA formation; and (ii) clouds generated during later stages of the reaction, when gasSOA mass reached its maximum. For each type of experiment, the protocol followed before beginning irradiation was the same as the one described in Brégonzio-Rozier et al. (2015). After overnight pumping, synthetic air was injected into the chamber to reach atmospheric pressure. This air was comprised of approximately $80 \% \mathrm{~N}_{2}$, produced from the evaporation of pressurized liquid nitrogen, and around $20 \% \mathrm{O}_{2}$ (Linde, 5.0). A known pressure of isoprene, leading to a mixing ratio of 800$850 \mathrm{ppb}$ in the chamber, was then introduced using a known volume glass bulb. Nitrous acid (HONO) was used as the $\mathrm{OH}$ source. HONO was produced by adding sulfuric acid $\left(10^{-2} \mathrm{M}\right)$ dropwise into a solution of $\mathrm{NaNO}_{2}(0.1 \mathrm{M})$ and flushed into the chamber using a flow of $\mathrm{N}_{2}$. $\mathrm{NO}_{x}$ was also introduced as a side product during HONO injection. Photooxidation of the system was then initiated by turning on the lamps (reaction time 0 corresponds to the irradiation start). Table 2 shows all of the experimental initial conditions, the number of generated clouds during each experiment and their maximum liquid water contents $\left(\mathrm{LWC}_{\max }\right)$ for both types of experiments.

In the first type of experiment, a diphasic system (gascloud), the aim was to produce evapo-condensation cycles in the presence of gaseous isoprene oxidation products prior to any gasSOA formation. This type of experiment started under dry conditions $(<5 \% \mathrm{RH})$, and the first water vapour injection, leading to $\sim 80 \% \mathrm{RH}$, was performed after $2 \mathrm{~h}$ of irradiation. This time corresponded to $\sim 80 \%$ of isoprene consumption and to the maximum concentration of the first generation isoprene gaseous reaction products (BrégonzioRozier et al., 2015) . After ca. $10 \mathrm{~min}$, the second water vapour injection, allowing cloud formation by saturation, was made. Two to three clouds were generated during each diphasic experiment (gas-cloud).

In the second type of experiment, a triphasic system (gasSOA-cloud), we tested the influence of cloud generation on isoprene photooxidation during a later stage of the reaction, i.e. when the first generation oxidation gaseous products of isoprene were mostly consumed, and when maximum gasSOA mass concentration was reached. In this case, in addition to the dissolution of gaseous species in the aqueous phase, some of the condensed matter could also dissolve in droplets. In this type of experiment, the formation of gasSOA was monitored under dry conditions $(<5 \% \mathrm{RH})$, and the first cloud was generated when the maximum gasSOA mass concentration was reached, generally after 7 to $9 \mathrm{~h}$ of irradiation, in a system containing more oxidized species than in the diphasic system. One to two clouds were generated during each triphasic experiment (gas-SOA-cloud). The variation of species under dry conditions for triphasic experiments presented here can be seen in Brégonzio-Rozier et al. (2015).

\subsection{Measurements}

A Fourier Transform Infra-Red spectrometer (FTIR, Brucker $^{\circledR}$, TENSOR 37) was used to measure concentrations of isoprene, MVK, MACR, formaldehyde, methylglyoxal, peroxyacetyl nitrate (PAN), formic acid, carbon monoxide (CO) and $\mathrm{NO}_{2}$ during dry conditions. Complementary to FTIR measurements, a proton-transfer time of flight mass spectrometer (PTR-ToF-MS 8000, Ionicon Analytik ${ }^{\circledR}$ ) was used for online gas-phase measurements in the $\mathrm{m} / \mathrm{z}$ range 10-200 including isoprene, the sum of MACR and MVK, 3-methylfuran (3 M-F), acetaldehyde, the sum of glycolaldehyde and acetic acid, acrolein, acetone, hydroxyacetone, 
Table 1. Comparisons of cloud properties between clouds generated in CESAM (23 clouds) and atmospheric clouds (Colvile et al., 1997; Herrmann, 2003).

\begin{tabular}{|c|c|c|}
\hline & CESAM & Atmosphere \\
\hline Droplet lifetime (min) & $6-13^{*}$ & $\approx 2-30$ \\
\hline Liquid water content $\left(\mathrm{g} \mathrm{m}^{-3}\right)$ & Maximum: $0.01-1.48$ & $0.05-3$ \\
\hline Mean mass-weighed diameter $(\mu \mathrm{m})$ & $3.5-8$ & $1-25$ \\
\hline Number concentration (droplet $\mathrm{cm}^{-3}$ ) & Maximum: $1 \times 10^{3}-5 \times 10^{4}$ Average: $4 \times 10^{2}-1 \times 10^{4}$ & $10^{2}-10^{3}$ \\
\hline Mean number-weighed diameter $(\mu \mathrm{m})$ & $2-4$ & $1-25$ \\
\hline
\end{tabular}

* Droplet lifetimes correspond to cloud lifetimes.

Table 2. Initial experimental conditions, maximum aerosol mass obtained under dry conditions and information on the generated clouds.

\begin{tabular}{|c|c|c|c|c|c|c|c|c|}
\hline Experiment $^{\mathrm{a}, \mathrm{b}}$ & $\begin{array}{r}\text { [Isoprene }]_{i} \\
(\mathrm{ppb})\end{array}$ & $\begin{array}{r}{[\mathrm{NO}]_{\mathrm{i}}} \\
(\mathrm{ppb})\end{array}$ & $\begin{array}{r}{\left[\mathrm{NO}_{2}\right]_{\mathrm{i}}^{\mathrm{c}}} \\
(\mathrm{ppb})\end{array}$ & $\begin{array}{r}{[\mathrm{HONO}]_{\mathrm{i}}} \\
(\mathrm{ppb})\end{array}$ & $\begin{array}{r}\Delta M_{0}^{\mathrm{d}} \\
\left(\mu \mathrm{g} \mathrm{m}^{-3}\right)\end{array}$ & $\begin{array}{r}T_{\mathrm{i}} \\
\left({ }^{\circ} \mathrm{C}\right)\end{array}$ & $\begin{array}{r}\text { Number of } \\
\text { clouds }\end{array}$ & $\begin{array}{l}\mathrm{LWC}_{\max }^{\mathrm{e}} \\
\left(\mathrm{g} \mathrm{m}^{-3}\right)\end{array}$ \\
\hline \multicolumn{9}{|c|}{ Diphasic experiments } \\
\hline D300113 & 817 & 95 & 71 & 161 & - & 21 & 2 & $\begin{array}{l}0.87 \\
0.45\end{array}$ \\
\hline D010213 & 800 & 103 & 49 & 133 & - & 21.1 & 2 & $\begin{array}{l}1.41 \\
0.74\end{array}$ \\
\hline D190313 & 831 & 123 & 58 & 99 & - & 19.8 & 3 & $\begin{array}{l}0.49 \\
0.77 \\
0.57\end{array}$ \\
\hline
\end{tabular}

\begin{tabular}{lcccccccc}
\hline \multicolumn{7}{c}{ Triphasic experiments } \\
\hline T160113 & 846 & 143 & 27 & 15 & $<0.1$ & 21.5 & 1 & 0.47 \\
\hline T280113 & 833 & 88 & 45 & 125 & 2.8 & 18.3 & 2 & 0.81 \\
& & & & & & & & 0.88 \\
\hline T130313 & 840 & 66 & $<1$ & 45 & 2.4 & 17.5 & 1 & n.m. ${ }^{\mathrm{f}}$ \\
\hline T250313 & 802 & 137 & 48 & 121 & 0.15 & 19.7 & 2 & 0.02 \\
& & & & & & & & 0.01 \\
\hline
\end{tabular}

a All experiments were carried out at initial $\mathrm{RH}<5 \%$. ${ }^{\mathrm{b}}$ Experimental IDs starting with "D" indicate diphasic experiments and experimental IDs starting with "T" indicate triphasic experiments. ${ }^{\mathrm{c}}$ Corrected for HONO interference. ${ }^{\mathrm{d}}$ gasSOA mass concentration using an effective density of $1.4 \mathrm{~g} \mathrm{~cm}^{-3}$ (Brégonzio-Rozier et al., 2015). There is no initial gasSOA formation for diphasic experiments. ${ }^{\mathrm{e}} \mathrm{LWC}_{\max }$ of each cloud generated. ${ }^{\mathrm{f}}$ not measured.

and a few other oxygenated VOCs (de Gouw et al., 2003a). The PTR-ToF-MS was connected to the chamber through a $120 \mathrm{~cm}$ long Peek ${ }^{\mathrm{TM}}$ capillary heated at $100^{\circ} \mathrm{C}$. Its signal was calibrated using a certified gas standard mixture (EU Version TO-14A Aromatics 110L, $100 \mathrm{ppbV}$ each). Considering the high amounts of water in the sampled air during and after cloud events, the sum of the primary $\mathrm{H}_{3} \mathrm{O}^{+}$and cluster ion $\mathrm{H}_{2} \mathrm{O} \cdot \mathrm{H}_{3} \mathrm{O}^{+}$signal derived from $\mathrm{H}_{3}^{18} \mathrm{O}^{+}(\mathrm{m} / \mathrm{z} 21.023)$ and $\mathrm{H}_{2}^{18} \mathrm{O} \cdot \mathrm{H}_{3} \mathrm{O}^{+}(\mathrm{m} / \mathrm{z} 39.033)$ count rate was taken into account for quantification (de Gouw and Warneke, 2007; de Gouw et al., 2003b; Ellis and Mayhew, 2014). A commercial UV absorption monitor (Horiba ${ }^{\circledR}$, APOA-370) was used to measure ozone. NO was monitored by a commercial chemiluminescence $\mathrm{NO}_{x}$ analyser (Horiba ${ }^{\circledR}$, APNA-370). During humid conditions, the $\mathrm{NO}_{2}$ signal from the $\mathrm{NO}_{x}$ monitor was used to determine $\mathrm{NO}_{2}$ mixing ratios, a correction was applied to take into account interferences due to the presence of $\mathrm{NO}_{y}$ during the experiments (Dunlea et al., 2007). An instrument developed in-house (NitroMAC), based on the wet chemical derivatization technique and HPLC-VIS (high-performance liquid chromatography visible) detection (Zhou et al., 1999) and described in detail by Michoud et al. (2014), was used to measure nitrous acid (HONO).

Aerosol size distribution from 10.9 to $478 \mathrm{~nm}$, total number and volume concentration of the particles were measured by a Scanning Mobility Particle Sizer (SMPS). This instrument includes a Differential Mobility Analyzer (DMA, TSI, model 3080) coupled with a Condensation Particle Counter (CPC, TSI, model 3010). A high resolution time-of-flight 
aerosol mass spectrometer (HR-ToF-AMS, Aerodyne) was used to measure chemical composition of non-refractory particulate matter, such as organics, nitrate and ammonium (Canagaratna et al., 2007; De Carlo et al., 2006). The HRToF-AMS was used under standard operating conditions (vaporizer at $600^{\circ} \mathrm{C}$ and electron ionization at $70 \mathrm{eV}$ ). Standard AMS calibration procedures using ammonium nitrate particles performed regularly, including the brute force single particle (BFSP) ionization efficiency calibration and size calibration. For HR-ToF-AMS data analysis, Squirrel (ToFAMS Analysis $1.51 \mathrm{H}$ ) and PIKA (ToF-AMS HR Analysis $1.10 \mathrm{H})$ packages for the software IGOR Pro 6.21 were used. The ionization efficiency obtained during BFSP calibration was used to calculate mass and standard adjustments were used to account for the relative ionization efficiency of each class of compounds (nitrate, sulfate, ammonium, and organics) (Canagaratna et al., 2007). The standard fragmentation table was adjusted to correct for the corrected air fragment column for the carrier gas. A collection efficiency of 0.5 was used for the organics to adjust for particle bounce at the heater (Middlebrook et al., 2012).

The SMPS and the HR-ToF-AMS were connected to the chamber through the same sampling line and dried with a $60 \mathrm{~cm}$ Nafion ${ }^{\circledR}$ tube (Permapure ${ }^{\mathrm{TM}}$, model MD-110). The relative humidity was continuously measured after drying and was never above $22 \% \mathrm{RH}$ at the outlet of the Nafion ${ }^{\circledR}$ tube. Systematically maintaining the relative humidity in the sampling line lower than the efflorescence point of any expected particulate matter was a critical parameter to effectively detect additional SOA and not a water uptake due to the change in relative humidity in the chamber. It is hence important to consider that all the SOA quantity, size distribution or AMS analysis discussed later in this paper concern dried SOA.

The size distributions of cloud droplets were determined by a white light optical particle counter (Welas ${ }^{\circledR} 2000$, Palas) using the refractive index of water $(1.33+0 i)$. The particle size range of this sensor was $0.6-40 \mu \mathrm{m}$. The Welas optical particle counter was calibrated using a calibration dust (CalDust 1100) exhibiting the same index of refraction as polystyrene latex (PSL) spheres.

\section{Results and discussion}

The aim of these experiments was to evaluate the influence of clouds on SOA formation in the isoprene / $\mathrm{NO}_{x} /$ air / light system. This system was already characterized in detail under dry conditions in the same chamber by Brégonzio-Rozier et al. (2015). To that purpose, as stated above, two new protocols were tested: a diphasic and a triphasic system. The corresponding results are shown in Figs. 1 to 4, and discussed hereafter.
Table 3. Summary of the maxima increases of the total particle mass concentration observed during cloud events for diphasic and triphasic experiments.

\begin{tabular}{|c|c|c|}
\hline Experiment* & $\begin{array}{l}\text { Increase in mass } \\
\qquad\left(\mu \mathrm{g} \mathrm{m}^{-3}\right)\end{array}$ & $\begin{array}{r}\text { Cloud lifetime } \\
(\mathrm{min})\end{array}$ \\
\hline \multicolumn{3}{|c|}{ Diphasic experiments } \\
\hline D300113 1st cloud & 8.0 & 12 \\
\hline D300113 2nd cloud & 5.1 & 9 \\
\hline D010213 1st cloud & 6.1 & 13 \\
\hline D010213 2nd cloud & 1.9 & 9 \\
\hline D190313 1st cloud & 3.9 & 11 \\
\hline D190313 2nd cloud & 2.6 & 12 \\
\hline D190313 3rd cloud & 2.7 & 11 \\
\hline \multicolumn{3}{|c|}{ Triphasic experiments } \\
\hline T160113 & 6.4 & 10 \\
\hline T280113 1st cloud & 6.5 & 10 \\
\hline T280113 2nd cloud & 5.5 & 10 \\
\hline $\mathrm{T} 130313$ & 7.2 & 11 \\
\hline T250313 1st cloud & 4.3 & 9 \\
\hline T250313 2nd cloud & 2.1 & 6 \\
\hline
\end{tabular}

* Experimental IDs starting with " $\mathrm{D}$ " indicate diphasic experiments, experimental IDs starting with " $\mathrm{T}$ " indicate triphasic experiments.

\subsection{SOA formation in the presence of a cloud}

During cloud events, a sudden and significant increase in dried SOA mass concentration was observed in both types of experiments (Fig. 1a and 1a'). This rise lasted from the outset of the cloud generation until its evaporation, i.e. during the whole cloud event. Increases in SOA mass concentrations for diphasic and triphasic experiments observed during cloud events are presented in Table 3. During the first cloud of each experiment, an increase in mass ranging from 3.9 to $8 \mu \mathrm{g} \mathrm{m}^{-3}$ was observed for diphasic experiments, and from 4.3 to $7.2 \mu \mathrm{g} \mathrm{m}^{-3}$ for triphasic experiments, which is more than 3 times higher than the increase observed in control experiments (Table S1 in the Supplement). The additional SOA formation observed in diphasic and triphasic experiments are called aqSOA formation hereafter. In triphasic experiments, no direct link between mass concentration levels of gasSOA prior to cloud generation and the maximum value reached by aqSOA during cloud events was observed. The comparison of triphasic and diphasic experiments shows that the observed increase in SOA mass concentration was the same order of magnitude, suggesting that the concentration, or even the initial presence of particulate phase (gasSOA), had no significant influence on aqSOA formation. The comparison between diphasic and triphasic experiments also suggests that the presence of a reacting mixture that underwent more oxidation steps, and thus composed of more oxidized compounds did not play a significant role in the amount of aqSOA produced. 

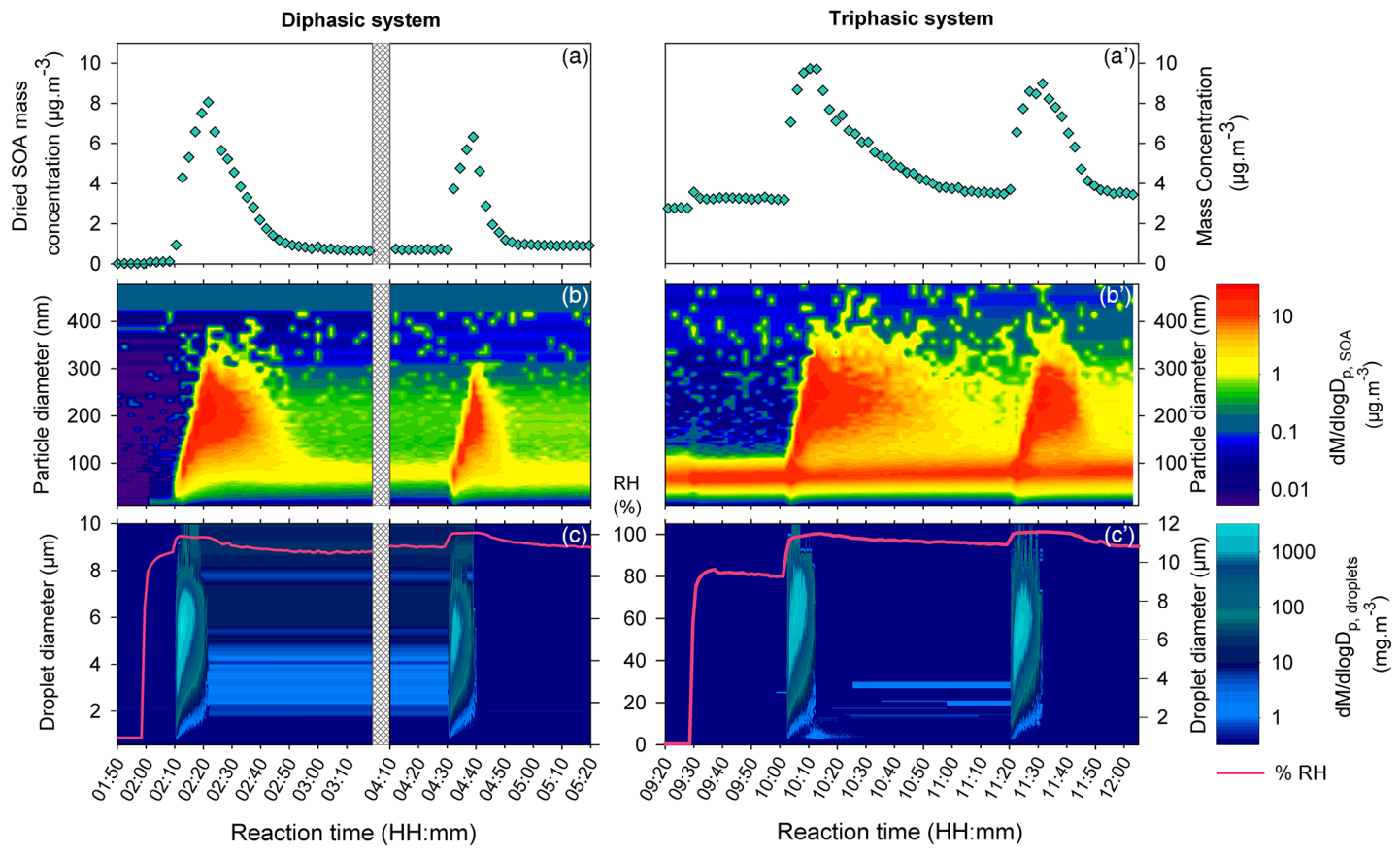

Figure 1. Effects of liquid phase clouds on SOA mass concentrations during two cloud events for typical diphasic (D300113, left panel) and triphasic (T280113, right panel) systems. Time profiles of (a and a') dried SOA mass concentration, (b and b') dried SOA mass size distribution, (c and $\mathbf{c}^{\prime}$ ) cloud droplet mass size distribution and relative humidity in the simulation chamber. A particle density of $1.4 \mu \mathrm{g} \mathrm{m}^{-3}$ was assumed.

The SOA mass size distributions (Fig. 1b) show that, for the diphasic experiment D300113, the mode of the distribution increased gradually during the first cloud event, with a maximum mode around $225 \mathrm{~nm}$ just before cloud evaporation. For the triphasic experiment T280113 (Fig. 1b'), the particle size distribution of the gasSOA formed under dry conditions increased during the first minute of the first cloud event, then a second mode, with larger size, was formed. While the initial mode showed no significant variation in size, the second mode increased in size gradually until reaching a diameter of around $250 \mathrm{~nm}$ before cloud evaporation. A link between high oxidation stage species and aqSOA formation cannot be highlighted in these experiments due to the subsistence of the initial mode (corresponding to gasSOA) and the systematic and reproducible formation of a second mode in all triphasic experiments. The observation of such a growing second mode, called the "droplet mode", has been previously underscored during field observations in the presence of water (Hering and Friedlander, 1982; John et al., 1990; Meng and Seinfeld, 1994). This "droplet mode" is hypothesized to be formed through volume-phase reactions in clouds and wet aerosols (Ervens et al., 2011) and has been found to be significantly enriched in highly oxidized organics, nitrates and organosulfates (Ervens et al., 2011).

For the subsequent clouds, smaller increases in SOA mass (from 1.9 to $5.1 \mathrm{\mu g} \mathrm{m}^{-3}$ for diphasic experiments, and from 2.1 to $5.5 \mu \mathrm{g} \mathrm{m}^{-3}$ for triphasic experiments, as shown in Table 3) were observed. No link between increases in SOA mass concentration and surface concentration of cloud droplets was observed to explain this difference, so a smaller cloud droplet size and/or lower water concentration was not the reason for these reduced aqSOA increases. However, it could be due to shorter cloud lifetimes after the initial cloud generation (Table 3 ) since aqSOA production stopped immediately after cloud evaporation in all experiments.

After cloud evaporation, the mode diameter and concentration of the measured distributions slowly decayed (Fig. 1a and $\left.\mathrm{a}^{\prime}\right)$. For diphasic experiments, the gradual decrease in concentration lasted for 25 to $35 \mathrm{~min}$ before reaching a plateau with a value of ca. $0.6 \mu \mathrm{g} \mathrm{m}^{-3}$, the same order of magnitude to that observed in control experiments (Fig. S2). A decay in SOA mass concentration was also observed after cloud evaporation for triphasic experiments. This gradual decrease lasted for $20 \mathrm{~min}$ to $1 \mathrm{~h}$ before reaching a stable SOA mass value close to the one observed before cloud generation (T280113 and T130313) and to a value of around $0.5-1 \mu \mathrm{g} \mathrm{m}^{-3}$ for experiments with lower initial gasSOA mass concentration (T160113 and T250313). This decrease in mass concentration was explained by a slow decay of the second aerosol size mode which tended to disappear when a stabilization of SOA mass concentrations was observed (Fig. $1 a^{\prime}$ and $b^{\prime}$ ).

Figure $1 b$ and $1 b^{\prime}$ show that, for both types of experiments (diphasic and triphasic systems), this slow decay in 
SOA mass observed after cloud evaporation was due to the shrinkage of particles, and was not linked to a direct particle wall-loss effect. It seems that this decay was due to wall re-partitioning of the SVOCs formed during the cloud event. Recently, it has been shown that losses of semi-volatile species to chamber walls could affect SOA formation rates during photooxidation experiments, due to a competition between condensation of SVOCs on the walls and on particles (Loza et al., 2010; Matsunaga and Ziemann, 2010; Zhang et al., 2014). SVOCs experience a continuous gas-wall partitioning in chambers, the extent of this effect depending on the molecular structure of the compound, the wall material and the experiment's organic loading, humidity and temperature. If production of additional semi-volatile species occurs in the droplet during cloud events, Henry's Law equilibrium suggests that these species are isolated from the walls in the droplets. After cloud dissipation, additional SOA mass is formed from these SVOCs which, at the same time, also experience a re-partitioning between particles and the walls. When the cloud is evaporated, since the available particle surface area is around 400 times smaller than the geometric wall surface area, the additional SOA mass decreases due to this equilibrium re-establishment under humid conditions. Wallloss kinetics data reported in the literature for a Teflon chamber (Matsunaga and Ziemann, 2010) have led to a characteristic time ranging from $1 \mathrm{~h}$ for non-polar species to $8 \mathrm{~min}$ for carbonyls: these results are compatible with the rates of the decays observed in our experiments (20 min to $1 \mathrm{~h}$ ). Furthermore, pseudo-first order rates for loss processes of organic compounds found in Wang et al. (2011) suggest that similar wall-loss kinetics are expected in the CESAM chamber.

Assuming that this observed SOA mass decay is due to wall re-partitioning, this process will not occur in the atmosphere, and aqSOA production can be determined using the maximum mass concentration measured at the end of each cloud event. In that case, aqSOA mass yield from isoprene photooxidation in the presence of clouds would be between 0.002 and 0.004 considering our results from the diphasic experiments, or between 2 and 4 times higher than mass yields observed for isoprene photooxidation experiments carried out under dry conditions with preliminary manual cleaning (Brégonzio-Rozier et al., 2015). For triphasic experiments, the observed increase of total SOA mass concentration at the end of each cloud event was at least a factor of 2 compared to the gasSOA mass concentrations reached under dry conditions prior cloud formation. Hence, it can be assumed that a substantial aqSOA production was observed in both types of experiments. Furthermore, the fact that additional SOA mass was formed in the triphasic system (i.e. in the second mode) seems to demonstrate that the role of cloud chemistry is not just to increase the rate of gas-phase oxidation reactions but is adding new chemistry.

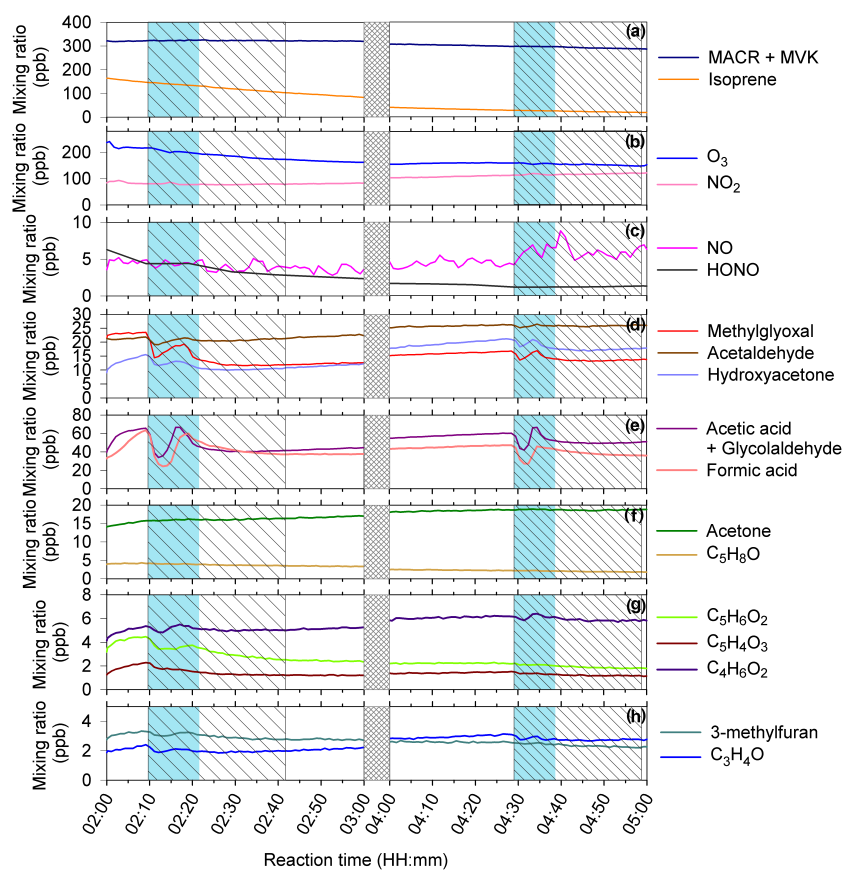

Figure 2. Time profiles of the gas phase reactants and isoprene oxidation products during a diphasic experiment (D300113). Blue areas indicate cloud events and hatched area indicate time needed for the PTR-ToF-MS signal to stabilize after the start of cloud generation (droplet and memory effects in the sampling line).

\subsection{Dissolution and reactivity of gaseous species in cloud droplets}

The time profiles of the gas phase reactants and oxidation products during a diphasic experiment are shown in Fig. 2 (similar profiles were observed for triphasic systems, see Fig. S3) in which two clouds were generated. Ozone, $\mathrm{NO}_{x}$ and HONO showed no significant change in their concentrations during cloud events (Fig. $2 b$ and c), with mixing ratios remaining at around 5 ppbv for HONO and NO. The concentrations of isoprene, the sum of MACR and MVK, acetone and $\mathrm{C}_{5} \mathrm{H}_{8} \mathrm{O}$ (compound that may be attributed to 2-methylbut-3-enal, Brégonzio-Rozier et al., 2015) also did not seem to be influenced by cloud generation (Fig. 2a and $\mathrm{f}$ ), as their concentrations remained unchanged during cloud events. On the contrary, more water soluble species (for example, methylglyoxal and formic acid) showed a sharp decrease in their concentrations during cloud generation (Fig. 2d, e, g and h). During each cloud event and for 20 additional minutes, the PTR-ToF-MS signal was not used due to possible droplet impaction in the heated sampling line. Using the concentrations of VOCs before each cloud event $\left(C_{\text {before }}\right)$ and $20 \mathrm{~min}$ after $\left(C_{\text {after }}\right)$, we calculated the gas phase concentration changes during cloud events $\left(\Delta C_{\text {cloud }}=C_{\text {before }}-C_{\text {after }}\right.$, see Table 4$)$. From these data, it can be noted that the loss of the most water soluble VOCs (e.g. glycolaldehyde, acetic acid, methylglyoxal, formic acid 
and hydroxyacetone) was significant during the cloud events (between 32 and $52 \%$, see Table 4). Isoprene was excluded from this calculation as its gas phase photochemical decay did not seem to be affected by the cloud events.

Following a hypothesis based on the kinetic determination of the mass transport of VOCs from the gas phase to water droplets (Schwartz, 1986), Henry's Law equilibrium was considered immediate at the start of cloud generation. This hypothesis was used to estimate the theoretical mass of individual VOCs transferred into the aqueous phase (see Supplement Sect. S1). The estimation was done using the experimental data of each gaseous VOC concentration prior cloud formation $\left(C_{\text {before }}\right)$ and using the measured LWC. The obtained values are summed and the total mass of VOCs theoretically transferred to the aqueous phase is compared to the mass of formed aqSOA in Table 4. It can be considered that the estimated transferred mass represents a lower limit since this calculation only considers the measured VOCs and thus neglects the contribution of other undetected VOCs such as the organic nitrates or glyoxal (which should contribute to an extent comparable to methylglyoxal or glycolaldehyde (Galloway et al., 2011). However, this lower limit is much higher than the maximum aerosol mass concentration increase observed during cloud events by more than 1 order of magnitude. This result thus suggests that, even if a small part of this dissolved organic matter (i.e. less than $10 \%$ ) would react in the aqueous phase or at the surface of the droplets during cloud events, leading to the formation of low volatile species, this would explain the observed amount of aqSOA formed.

Table 4 shows that, for triphasic experiments, the measured VOC losses in the gas phase during the cloud events ( $\sum \Delta C_{\text {cloud }}$ ) were between 1.5 and 3 times higher than the theoretical quantity (Henry's Law equilibrium) transferred from the gas phase to the droplets. This result suggests the following: (1) a reactive uptake of VOCs toward the aqueous phase is taking place, shifting the Henry's Law equilibrium and increasing the amount of VOCs transferred to the droplets, and (2) a large part of this solubilized organic matter is transformed into semi-volatile species on the time scale of the cloud event. This result implies a very fast reactivity in the aqueous phase, which is in agreement with the observed rapid aqSOA production.

\subsection{SOA formation details and chemical composition}

For both diphasic and triphasic systems, aqSOA production reached a value of ca. $0.02 \mu \mathrm{g} \mathrm{m}^{-3} \mathrm{~s}^{-1}$ during the first $2 \mathrm{~min}$ of the cloud event (Fig. S4). This value then decreased to approximately $0.005 \mu \mathrm{g} \mathrm{m}^{-3} \mathrm{~s}^{-1}$ until cloud dissipation. Keeping the hypothesis of an instantaneous Henry's Law equilibrium, the highest aqSOA production observed at the beginning of the cloud event is probably due to the dissolution of the soluble species as $2 \mathrm{~min}$ is in the order of magnitude of the mixing time in the CESAM chamber (ca. $100 \mathrm{~s}$, Wang et al., 2011), while the second (lower) production phase may be related to the shift of this equilibrium due to possible reactivity in the aqueous phase.

In diphasic experiments, the brevity of the aqSOA formation, the small size of these aerosols after cloud evaporation (a mass mode diameter of less than $100 \mathrm{~nm}$ ) and a reduced collection efficiency for particles with a $<100 \mathrm{~nm}$ aerodynamic diameter in the HR-ToF-AMS, limit quantitative results. The results for elemental ratios $(\mathrm{O} / \mathrm{C}, \mathrm{H} / \mathrm{C}$, and $\mathrm{OM} / \mathrm{OC}$ ) were hence restricted to the first cloud event and around $10 \mathrm{~min}$ after, when the diameter mode of the distribution was sufficiently high enough to achieve a reliable signal from the HR-ToF-AMS. Temporal variation of elemental ratios and density for aqSOA in diphasic and triphasic systems for the first cloud event are presented in Fig. 3. Temporal evolutions of these elemental ratios for each system were reproducible. A slight increase of $\mathrm{O} / \mathrm{C}$ and $\mathrm{OM} / \mathrm{OC}$ ratios was observed between 5 and 10 min after the first cloud generation, but these variations remain insignificant considering the measurement uncertainties given by Aiken et al. (2008). The average values of elemental ratios in diphasic and triphasic systems (calculated using values obtained during and after the first cloud event of each experiment) showed no significant difference compared to the results obtained under dry conditions (Table 5). We observed no change in the density, which remains at $1.40 \pm 0.04 \mu \mathrm{g} \mathrm{m}^{-3}$ as under dry conditions (Brégonzio-Rozier et al., 2015). The SOA effective density was obtained by calculation based on the elemental composition of aerosol from AMS measurements (Kuwata et al., 2012).

To complete this SOA composition study, mass spectra and size distribution measured before, during, and after cloud events in a typical triphasic experiment are presented in Fig. 4. Comparison of the size distributions in these various phases of the experiments shows the persistence of the initial distribution of organic compounds (aerodynamic mode around $100 \mathrm{~nm}$ ). When maximum aqSOA mass concentration is reached (Fig. 4b), we note the presence of a second mode (around $300 \mathrm{~nm}$ ) corresponding to an aerosol composed of organics, nitrates and mass fragments interpreted as ammonium. The particle sizes and compositions observed for this second mode were very similar to what was observed during cloud events for diphasic experiments (Fig. S5). In triphasic experiments, the SOA composition, which was around $100 \%$ organics before cloud generation (Fig. 4a), changed to a composition of organics (39\%), nitrates $(48 \%)$ and ammonium (13\%) during the cloud event (Fig. 4b).

The presence of ammonium fragments is difficult to explain and it must be underlined that its contribution was close to the detection limits of the AMS. In the gas phase, the corresponding $\mathrm{NH}_{3}$ contribution was far below the detection limits of the gas phase analytical techniques (PTR-ToF-MS and FTIR). $\mathrm{NH}_{3}$ contamination has been observed - and remained unexplained - in a comparable simulation chamber (Bianchi et al., 2012). By contrast, the presence of nitrates is 
Table 4. Comparison between measured VOC loss, potential aqueous phase dissolution of gas phase species and particle formation during cloud events of each system.

\begin{tabular}{|c|c|c|c|c|c|c|}
\hline & \multicolumn{2}{|c|}{ Diphasic system } & \multicolumn{2}{|c|}{ Triphasic system } & \multirow[b]{3}{*}{$K_{\mathrm{H}}^{*}\left(\mathrm{M} \mathrm{atm}^{-1}\right)$} & \multirow[b]{3}{*}{ Reference } \\
\hline & D300113 & D010213 & $\mathrm{T} 160113$ & $\mathrm{~T} 280113$ & & \\
\hline & \multicolumn{4}{|c|}{$\Delta C_{\text {cloud }}^{\mathrm{a}}\left(\mu \mathrm{g} \mathrm{m}^{-3}\right)$ and relative change $(\%)$} & & \\
\hline Isoprene $\mathrm{g}^{\mathrm{g}}$ & 0 & 0 & 0 & 0 & $3.4 \times 10^{-2}$ & Leng et al. (2013) \\
\hline $\mathrm{C}_{4} \mathrm{H}_{6} \mathrm{O}^{\mathrm{g}}$ : & & & & & & \\
\hline MACR & 0 & 0 & 0 & 0 & 9.5 & Hilal et al. (2008) \\
\hline MVK & & & & & 18 & Hilal et al. (2008) \\
\hline Acrolein & $1.1(19 \%)$ & $0.9(16 \%)$ & $2.7(41 \%)$ & $2.3(30 \%)$ & 9.5 & Hilal et al. (2008) \\
\hline 3-Methylfuran & $1.7(15 \%)$ & $1.7(14 \%)$ & 0 & 0 & $6.1^{\mathrm{d}}$ & Hilal et al. (2008) \\
\hline Acetaldehyde & $1.3(3 \%)$ & $0.7(2 \%)$ & $4.3(9 \%)$ & $5.6(11 \%)$ & 13 & Benkelberg et al. (1995) \\
\hline Acetone $\mathrm{g}$ & 0 & 0 & 0 & 0 & 33 & Poulain et al. (2010) \\
\hline Formaldehyde & - & - & - & - & $3.2 \times 10^{3}$ & Staudinger and Roberts (1996) \\
\hline Methylglyoxal & $34.4(49 \%)$ & $32.1(49 \%)$ & $23(52 \%)$ & $31.2(42 \%)$ & $3.7 \times 10^{3}$ & Betterton and Hoffmann (1988) \\
\hline $\mathrm{C}_{2} \mathrm{H}_{4} \mathrm{O}_{2}$ : & $59.4(37 \%)$ & $58.4(36 \%)$ & $141.4(46 \%)$ & $143.2(35 \%)$ & & \\
\hline Acetic acid ${ }^{b}$ & & & & & $4.6 \times 10^{3}$ & Staudinger and Roberts (2001) \\
\hline Glycolaldehyde & & & & & $4.1 \times 10^{4}$ & Betterton and Hoffmann (1988) \\
\hline Formic acid ${ }^{b}$ & $49.1(41 \%)$ & $47.8(38 \%)$ & $107.8(49 \%)$ & $177.2(48 \%)$ & $6.7 \times 10^{3}$ & Staudinger and Roberts (2001) \\
\hline Hydroxyacetone & $15.4(32 \%)$ & $18.2(37 \%)$ & $32.1(47 \%)$ & $26.3(36 \%)$ & $7.8 \times 10^{3}$ & Zhou et al. (2009) \\
\hline $\mathrm{C}_{4} \mathrm{H}_{6} \mathrm{O}_{2}$ : & $1.4(7 \%)$ & $2.2(11 \%)$ & $3.6(26 \%)$ & $3.2(18 \%)$ & & \\
\hline 3-Oxobutanal ${ }^{\mathrm{c}}$ & & & & & $1.1 \times 10^{4}$ & Estimated using GROMHE \\
\hline HydroxyMVK ${ }^{c}$ & & & & & $1.9 \times 10^{3}$ & (Raventos-Duran et al., 2010) \\
\hline $\mathrm{C}_{5} \mathrm{H}_{8} \mathrm{O}^{\mathrm{g}}:$ & 0 & 0 & 0 & 0 & & Estimated using GROMHE \\
\hline 2-Methylbut-3-enal ${ }^{\mathrm{c}}$ & & & & & 27.1 & (Raventos-Duran et al., 2010) \\
\hline $\begin{array}{l}\mathrm{C}_{5} \mathrm{H}_{6} \mathrm{O}_{2} \text { : } \\
\text { 2-Methyl-but-2-enedial }\end{array}$ & $7.6(41 \%)$ & $8(39 \%)$ & $17.6(55 \%)$ & $3.2(36 \%)$ & $2.0 \times 10^{4}$ & $\begin{array}{l}\text { Estimated using GROMHE } \\
\text { (Raventos-Duran et al., 2010) }\end{array}$ \\
\hline $\mathrm{C}_{5} \mathrm{H}_{4} \mathrm{O}_{3}^{\mathrm{c}}$ & $4.6(43 \%)$ & $5(46 \%)$ & $8.2(69 \%)$ & $3.2(54 \%)$ & $\gg 10^{4}$ & - \\
\hline $\begin{array}{l}\text { Measured VOCs loss after cloud } \\
\text { evaporation } \mathrm{e}\left(\mu \mathrm{g} \mathrm{m}^{-3}\right)\end{array}$ & 176 & 175 & 341 & 395 & & \\
\hline $\begin{array}{l}\text { Expected VOCs dissolution in water at } \\
\text { cloud start }^{\mathrm{f}}\left(\mu \mathrm{g} \mathrm{m}^{-3}\right)\end{array}$ & 136 & 198 & 121 & 272 & & \\
\hline $\begin{array}{l}\text { Maximum particle mass concentration } \\
\text { enhancement measured during cloud } \\
\text { event }\left(\mu \mathrm{g} \mathrm{m}^{-3}\right)\end{array}$ & 8.0 & 6.1 & 6.4 & 6.5 & & \\
\hline $\mathrm{LWC}_{\max }$ first cloud $\left(\mathrm{g} \mathrm{m}^{-3}\right)$ & 0.87 & 1.41 & 0.47 & 0.81 & & \\
\hline
\end{tabular}
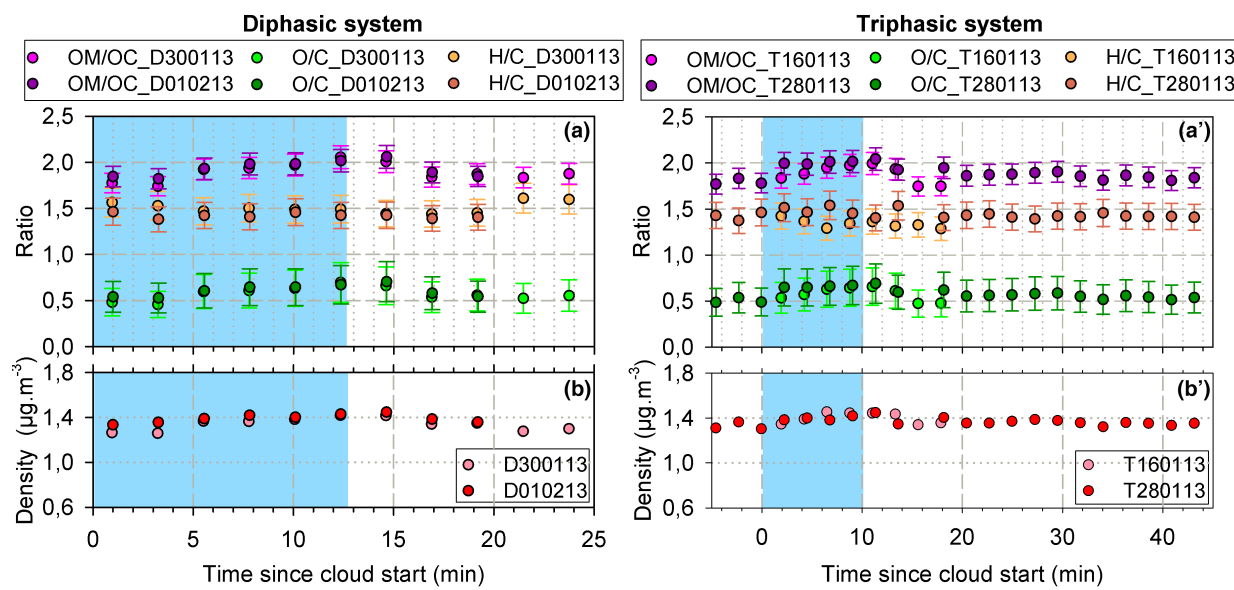

Figure 3. Time profiles of (a and a') $\mathrm{O} / \mathrm{C}, \mathrm{OM} / \mathrm{OC}$ and $\mathrm{H} / \mathrm{C}$ ratios (with the measurement uncertainty as determined by Aiken et al., 2008), and (b and b') particle density for diphasic (left panel) and triphasic (right panel) experiments. Blue areas indicate cloud events. 
Table 5. Average elemental ratios of SOA from isoprene photooxidation under dry conditions and after cloud generation (diphasic and triphasic experiments). Values in parentheses reflect the measurement uncertainty as determined by Aiken et al. (2008).

\begin{tabular}{llll}
\hline $\mathrm{O} / \mathrm{C}$ & $\mathrm{OM} / \mathrm{OC}$ & $\mathrm{H} / \mathrm{C}$ & Reference \\
\hline $0.58( \pm 0.18)$ & $1.90( \pm 0.11)$ & $1.45( \pm 0.15)$ & Diphasic experiments \\
$0.58( \pm 0.18)$ & $1.89( \pm 0.11)$ & $1.39( \pm 0.14)$ & Triphasic experiments \\
$0.60( \pm 0.19)$ & $1.92( \pm 0.12)$ & $1.43( \pm 0.14)$ & Dry conditions (Brégonzio-Rozier et al., 2015) \\
\hline
\end{tabular}
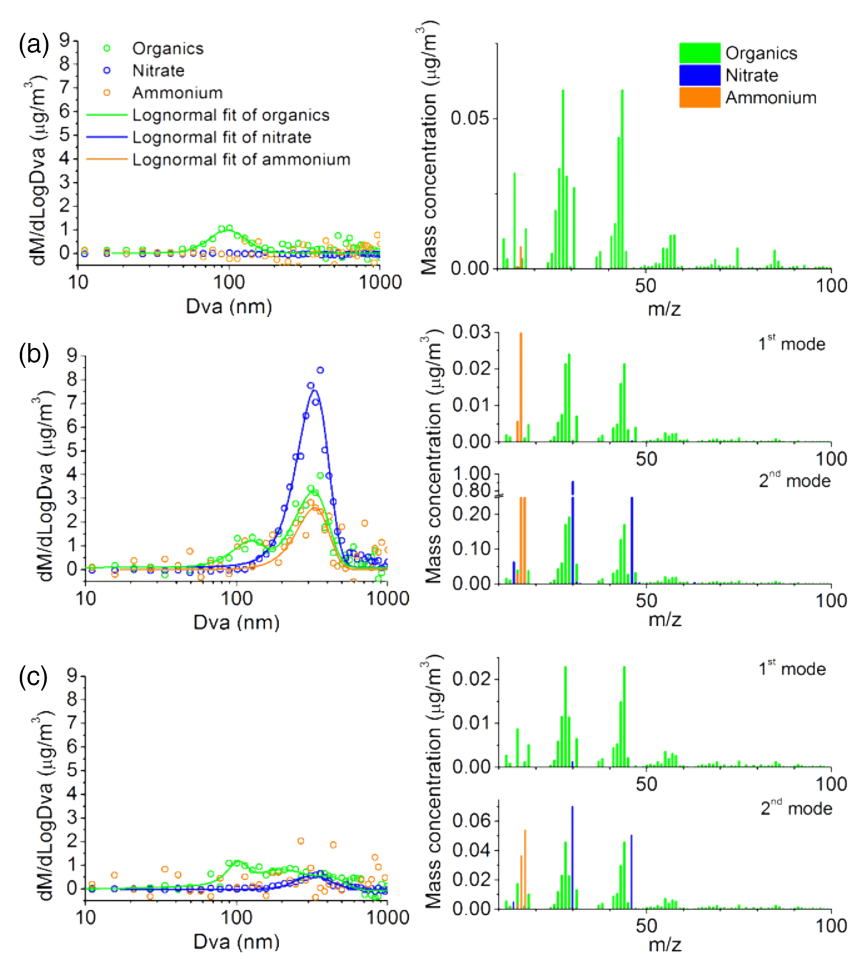

Figure 4. SOA chemical composition measured by an HR-ToFAMS during a triphasic experiment (T280113) (a) before, (b) during and (c) 30 min after a cloud event. Right panels: mass spectra of dried aerosol averaged over $10 \mathrm{~min}$ (organic fragments are in green, nitrate fragments in blue and ammonium fragments in orange); Left panels: dried aerosol mass size distributions.

in good agreement with field observations (Dall'Osto et al., 2009; Giorio et al., 2015).

The presence of nitrates could be due to the transfer from the gas phase to the aqueous phase of nitric acid and organonitrates formed by isoprene photooxidation in the presence of $\mathrm{NO}_{x}$ (Darer et al., 2011; Perring et al., 2013), although no high-resolution organonitrate peaks were observed in the HR-ToF-AMS data and the $\mathrm{NO} / \mathrm{NO}_{2}$ mass peak ratios calculated from the aerosol mass spectra, proposed to be used to ascertain whether the presence or absence of organonitrates in HR-ToF-AMS data was the same as that of inorganic nitrate (Farmer et al., 2010). Even if organonitrates were present, their hydrolysis in the aqueous phase could probably not explain the presence of nitrates as Nguyen et al. (2012) showed that only less than $2 \%$ of organonitrates derived from isoprene $+\mathrm{NO}_{x}$ undergo hydrolysis within up to $4 \mathrm{~h}$ of reaction in the aqueous phase.

After cloud evaporation, a slow decrease of the second aerosol size mode was observed (Fig. 4c), which can be linked to the aqSOA mass concentration decay. Photolysis of particulate organonitrates was discarded as a possible explanation for this decay because controlled experiments have been performed by switching the light just after cloud evaporation: they lead to the same observations. Hydrolysis of organonitrates cannot be totally excluded. Nevertheless, although hydrolysis lifetimes of tertiary organonitrates have been found to be in the range of a few minutes in diluted solutions (Darer et al., 2011; Hu et al., 2011; Rindelaub et al., 2015), as already mentioned, this process is likely slow and of small importance for a complex mixture of SOA organonitrates derived from isoprene $+\mathrm{NO}_{x}$ (Nguyen et al., 2012). Furthermore, it is expected that these nitrates lead to polyols (Darer et al., 2011), which would preferentially remain in the particulate phase due to their low vapour pressures (Compernolle and Müller, 2014). If polyols formation was observed in our experiments, we would have observed a loss of nitrates, but not of the associated organic fragments, which is not consistent with our observations (Fig. $4 \mathrm{~b}$ and c). As a result, it suggests that a chemical origin for the decay of the second mode (which contains a large part of nitrates) is quite unlikely, and thus, that a re-partitioning between particles and the walls is far more likely.

\section{Atmospheric implications and conclusion}

The impact of cloud events on an isoprene / $\mathrm{NO}_{x}$ system in the presence of light and at different oxidation stages was investigated in a stainless steel simulation chamber. It was observed that a single and relatively short cloud condensation cycle in the presence of irradiation led to a significant aqSOA mass yield (0.002-0.004) with values between 2 and 4 times higher than that observed for isoprene photooxidation experiments carried out under dry conditions (Brégonzio-Rozier et al., 2015). Even if no significant changes were noted in the SOA elemental ratios, it appears that the bulk chemical aerosol composition was significantly impacted by cloud events since an additional formation of particulate matter containing organics, nitrate and ammonium fragments was observed. This formed aqSOA seems 
to be metastable in the simulation chamber environment due to gas phase/wall repartitioning after cloud dissipation. However, it can be assumed that in a real cloud, in the absence of walls, the semi-volatile organic matter formed would remain in the aerosol/hydrometeor phase due to re-condensation on pre-existing aerosol or condensation/dissolution on the remaining droplets. Since clouds undergo several evapocondensation cycles in the atmosphere, this study highlights the potentially great importance of cloud chemistry on the secondary aerosol budget. This study also shows the complexity of working with a multiphase system with cloud generation disturbing equilibria established in dry conditions. However, as highlighted by Daumit et al. (2014) and the results obtained in this study, it also shows the importance of investigating that kind of systems, which is not only more realistic but also which is the only way to experimentally study the competition between phase transfer, surface reaction and homogeneous phase transformation.

Aqueous SOA formation was characterized by the appearance of a second mode that can be connected with the "droplet mode", which has been previously detected in the ambient atmosphere during early studies (Hering and Friedlander, 1982; John et al., 1990; Meng and Seinfeld, 1994). Evidence was obtained by John et al. (1990) that this growing second mode grew out of the condensation mode by the addition of water and aqueous phase oxidation products. Our experiment provided here a direct simulation of the origin of a "droplet mode" in the atmospheric aerosol.

Finally, using the elemental ratios obtained in this study (Fig. 3), the aqSOA carbon mass yields obtained in this study range between 0.002 to 0.004 , which is 1 order of magnitude lower than those predicted by a multiphase model performed on isoprene multiphase photochemistry under comparable $\mathrm{VOC}_{(\mathrm{ppbC})} / \mathrm{NO}_{x(\mathrm{ppb})}$ ratios (Ervens et al., 2008). However, the model was run using different initial conditions compared to our experiments: much lower initial concentrations of isoprene and $\mathrm{NO}_{x}$ (by a factor of $\sim 10^{3}$ and $\sim 100$ respectively), pre-existing wet seed particles, and lower liquid water content during cloud events were used in the model. The observed difference between model and experimental results thus supports the great need for the development of simulation chamber multiphase models in order to accurately compare experimental results with the known multiphase photochemical processes. Overall, our results emphasize the need to use the same integrated multiphase approach on other chemical systems and to integrate these results in atmospheric chemistry models to improve SOA formation determinations.

\section{The Supplement related to this article is available online at doi:10.5194/acp-16-1747-2016-supplement.}

Acknowledgements. The authors thank Arnaud Allanic, Sylvain Ravier, Pascal Renard and Pascal Zapf for their contributions in the experiments. The authors also acknowledge the institutions that have provided financial support: the French National Institute for Geophysical Research (CNRS-INSU) within the LEFE-CHAT program through the project "Impact de la chimie des nuages sur la formation d'aérosols organiques secondaires dans l'atmosphère" and the French National Agency for Research (ANR) project CUMULUS ANR-2010-BLAN-617-01. This work was also supported by the EC within the I3 project "Integrating of European Simulation Chambers for Investigating Atmospheric Processes" (EUROCHAMP-2, contract no. 228335). The authors thank the MASSALYA instrumental platform (Aix Marseille Université, lce.univ-amu.fr) for the analysis and measurements used in this paper.

\section{Edited by: F. Keutsch}

\section{References}

Aiken, A. C., Decarlo, P. F., Kroll, J. H., Worsnop, D. R., Huffman, J. A., Docherty, K. S., Ulbrich, I. M., Mohr, C., Kimmel, J. R., Sueper, D., Sun, Y., Zhang, Q., Trimborn, A., Northway, M., Ziemann, P. J., Canagaratna, M. R., Onasch, T. B., Alfarra, M. R., Prevot, A. S. H., Dommen, J., Duplissy, J., Metzger, A., Baltensperger, U., and Jimenez, J. L.: O / C and OM / OC ratios of primary, secondary, and ambient organic aerosols with high-resolution time-of-flight aerosol mass spectrometry, Environ. Sci. Technol., 42, 4478-4485, 2008.

Altieri, K. E., Seitzinger, S. P., Carlton, A. G., Turpin, B. J., Klein, G. C., and Marshall, A. G.: Oligomers formed through in-cloud methylglyoxal reactions: Chemical composition, properties, and mechanisms investigated by ultra-high resolution FT-ICR mass spectrometry, Atmos. Environ., 42, 1476-1490, 2008.

Bateman, A. P., Nizkorodov, S. A., Laskin, J., and Laskin, A.: Photolytic processing of secondary organic aerosols dissolved in cloud droplets, Phys. Chem. Chem. Phys., 13, 12199-12212, 2011.

Benkelberg, H. J., Hamm, S., and Warneck, P.: Henry's law coefficients for aqueous solutions of acetone, acetaldehyde and acetonitrile, and equilibrium constants for the addition compounds of acetone and acetaldehyde with bisulfite, J. Atmos. Chem., 20, 17-34, 1995.

Betterton, E. A. and Hoffmann, M. R.: Henry's law constants of some environmentally important aldehydes, Environ. Sci. Technol., 22, 1415-1418, 1988.

Bianchi, F., Dommen, J., Mathot, S., and Baltensperger, U.: Online determination of ammonia at low pptv mixing ratios in the CLOUD chamber, Atmos. Meas. Tech., 5, 1719-1725, doi:10.5194/amt-5-1719-2012, 2012.

Brégonzio-Rozier, L., Siekmann, F., Giorio, C., Pangui, E., Morales, S. B., Temime-Roussel, B., Gratien, A., Michoud, V., Ravier, S., Cazaunau, M., Tapparo, A., Monod, A., and Doussin, J.-F.: Gaseous products and secondary organic aerosol formation during long term oxidation of isoprene and methacrolein, Atmos. Chem. Phys., 15, 2953-2968, doi:10.5194/acp-15-29532015, 2015. 
Canagaratna, M. R., Jayne, J. T., Jimenez, J. L., Allan, J. D., Alfarra, M. R., Zhang, Q., Onasch, T. B., Drewnick, F., Coe, H., Middlebrook, A., Delia, A., Williams, L. R., Trimborn, A. M., Northway, M. J., DeCarlo, P. F., Kolb, C. E., Davidovits, P., and Worsnop, D. R.: Chemical and microphysical characterization of ambient aerosols with the aerodyne aerosol mass spectrometer, Mass Spectrom. Rev., 26, 185-222, 2007.

Carlton, A. G. and Turpin, B. J.: Particle partitioning potential of organic compounds is highest in the Eastern US and driven by anthropogenic water, Atmos. Chem. Phys., 13, 10203-10214, doi:10.5194/acp-13-10203-2013, 2013.

Carlton, A. G., Turpin, B. J., Lim, H. J., Altieri, K. E., and Seitzinger, S.: Link between isoprene and secondary organic aerosol (SOA): Pyruvic acid oxidation yields low volatility organic acids in clouds, Geophys. Res. Lett., 33, L06822, doi:10.1029/2005GL025374, 2006.

Carlton, A. G., Turpin, B. J., Altieri, K. E., Seitzinger, S., Reff, A., Lim, H. J., and Ervens, B.: Atmospheric oxalic acid and SOA production from glyoxal: Results of aqueous photooxidation experiments, Atmos. Environ., 41, 7588-7602, 2007.

Colvile, R. N., Bower, K. N., Choularton, T. W., Gallagher, M. W., Beswick, K. M., Arends, B. G., Kos, G. P. A., Wobrock, W., Schell, D., Hargreaves, K. J., Storeton-West, R. L., Cape, J. N., Jones, B. M. R., Wiedensohler, A., Hansson, H. C., Wendisch, M., Acker, K., Wieprechtj, W., Pahl, S., Winkler, P., Berner, A., Kruisz, C., and Gieray, R.: Meteorology of the great dun fell cloud experiment 1993, Atmos. Environ., 31, 2407-2420, 1997.

Compernolle, S. and Müller, J.-F.: Henry's law constants of polyols, Atmos. Chem. Phys., 14, 12815-12837, doi:10.5194/acp-1412815-2014, 2014.

Couvidat, F., Sartelet, K., and Seigneur, C.: Investigating the Impact of Aqueous-Phase Chemistry and Wet Deposition on Organic Aerosol Formation Using a Molecular Surrogate Modeling Approach, Environ. Sci. Technol., 47, 914-922, 2013.

Dall'Osto, M., Harrison, R. M., Coe, H., and Williams, P.: Real-time secondary aerosol formation during a fog event in London, Atmos. Chem. Phys., 9, 2459-2469, doi:10.5194/acp-9-2459-2009, 2009.

Darer, A. I., Cole-Filipiak, N. C., O'Connor, A. E., and Elrod, M. J.: Formation and Stability of Atmospherically Relevant IsopreneDerived Organosulfates and Organonitrates, Environ. Sci. Technol., 45, 1895-1902, 2011.

Daumit, K. E., Carrasquillo, A. J., Hunter, J. F., and Kroll, J. H.: Laboratory studies of the aqueous-phase oxidation of polyols: submicron particles vs. bulk aqueous solution, Atmos. Chem. Phys., 14, 10773-10784, doi:10.5194/acp-14-10773-2014, 2014.

De Carlo, P. F., Kimmel, J. R., Trimborn, A., Northway, M. J., Jayne, J. T., Aiken, A. C., Gonin, M., Fuhrer, K., Horvath, T., Docherty, K. S., Worsnop, D. R., and Jimenez, J. L.: Field-Deployable, High-Resolution, Time-of-Flight Aerosol Mass Spectrometer, Anal. Chem., 78, 8281-8289, 2006.

de Gouw, J. and Warneke, C.: Measurements of volatile organic compounds in the earth's atmosphere using proton-transferreaction mass spectrometry, Mass Spectrom. Rev., 26, 223-257, 2007.

de Gouw, J., Warneke, C., Karl, T., Eerdekens, G., van der Veen, C., and Fall, R.: Sensitivity and specificity of atmospheric trace gas detection by proton-transfer-reaction mass spectrometry, Int. J. Mass Spectrom., 223-224, 365-382, 2003 a. de Gouw, J. A., Goldan, P. D., Warneke, C., Kuster, W. C., Roberts, J. M., Marchewka, M., Bertman, S. B., Pszenny, A. A. P., and Keene, W. C.: Validation of proton transfer reaction-mass spectrometry (PTR-MS) measurements of gas-phase organic compounds in the atmosphere during the New England Air Quality Study (NEAQS) in 2002, J. Geophys. Res.-Atmos., 108, 4682, doi:10.1029/2003JD003863, 2003b.

Dommen, J., Metzger, A., Duplissy, J., Kalberer, M., Alfarra, M. R., Gascho, A., Weingartner, E., Prevot, A. S. H., Verheggen, B., and Baltensperger, U.: Laboratory observation of oligomers in the aerosol from isoprene/NOx photooxidation, Geophys. Res. Lett., 33, L13805, doi:10.1029/2006GL026523, 2006.

Dunlea, E. J., Herndon, S. C., Nelson, D. D., Volkamer, R. M., San Martini, F., Sheehy, P. M., Zahniser, M. S., Shorter, J. H., Wormhoudt, J. C., Lamb, B. K., Allwine, E. J., Gaffney, J. S., Marley, N. A., Grutter, M., Marquez, C., Blanco, S., Cardenas, B., Retama, A., Ramos Villegas, C. R., Kolb, C. E., Molina, L. T., and Molina, M. J.: Evaluation of nitrogen dioxide chemiluminescence monitors in a polluted urban environment, Atmos. Chem. Phys., 7, 2691-2704, doi:10.5194/acp-7-2691-2007, 2007.

Edney, E. O., Kleindienst, T. E., Jaoui, M., Lewandowski, M., Offenberg, J. H., Wang, W., and Claeys, M.: Formation of 2-methyl tetrols and 2-methylglyceric acid in secondary organic aerosol from laboratory irradiated isoprene/NOX/SO2/air mixtures and their detection in ambient PM2.5 samples collected in the eastern United States, Atmos. Environ., 39, 5281-5289, 2005.

El Haddad, I., Yao Liu, Nieto-Gligorovski, L., Michaud, V., Temime-Roussel, B., Quivet, E., Marchand, N., Sellegri, K., and Monod, A.: In-cloud processes of methacrolein under simulated conditions - Part 2: Formation of secondary organic aerosol, Atmos. Chem. Phys., 9, 5107-5117, doi:10.5194/acp-9-5107-2009, 2009.

Ellis, A. M. and Mayhew, C. A.: Proton Transfer Reaction Mass Spectrometry Principles and Applications, John Wiley \& Sons Ltd, Chichester, United Kingdom, 2014.

Ervens, B., Carlton, A. G., Turpin, B. J., Altieri, K. E., Kreidenweis, S. M., and Feingold, G.: Secondary organic aerosol yields from cloud-processing of isoprene oxidation products, Geophys. Res. Lett., 35, L02816, doi:10.1029/2007GL031828, 2008.

Ervens, B., Turpin, B. J., and Weber, R. J.: Secondary organic aerosol formation in cloud droplets and aqueous particles (aqSOA): a review of laboratory, field and model studies, Atmos. Chem. Phys., 11, 11069-11102, doi:10.5194/acp-1111069-2011, 2011.

Ervens, B., Sorooshian, A., Lim, Y. B., and Turpin, B. J.: Key parameters controlling $\mathrm{OH}$-initiated formation of secondary organic aerosol in the aqueous phase (aqSOA), J. Geophys. Res.Atmos., 119, 3997-4016, 2014.

Farmer, D. K., Matsunaga, A., Docherty, K. S., Surratt, J. D., Seinfeld, J. H., Ziemann, P. J., and Jimenez, J. L.: Response of an aerosol mass spectrometer to organonitrates and organosulfates and implications for atmospheric chemistry, Proc. Natl. Acad. Sci. USA, 107, 6670-6675, 2010.

Galloway, M. M., Huisman, A. J., Yee, L. D., Chan, A. W. H., Loza, C. L., Seinfeld, J. H., and Keutsch, F. N.: Yields of oxidized volatile organic compounds during the $\mathrm{OH}$ radical initiated oxidation of isoprene, methyl vinyl ketone, and methacrolein under high-NOx conditions, Atmos. Chem. Phys., 11, 10779-10790, doi:10.5194/acp-11-10779-2011, 2011. 
Giorio, C., Tapparo, A., Dall'Osto, M., Beddows, D. C. S., EsserGietl, J. K., Healy, R. M., and Harrison, R. M.: Local and Regional Components of Aerosol in a Heavily Trafficked Street Canyon in Central London Derived from PMF and Cluster Analysis of Single-Particle ATOFMS Spectra, Environ. Sci. Technol., 49, 3330-3340, 2015.

Hallquist, M., Wenger, J. C., Baltensperger, U., Rudich, Y., Simpson, D., Claeys, M., Dommen, J., Donahue, N. M., George, C., Goldstein, A. H., Hamilton, J. F., Herrmann, H., Hoffmann, T., Iinuma, Y., Jang, M., Jenkin, M. E., Jimenez, J. L., Kiendler-Scharr, A., Maenhaut, W., McFiggans, G., Mentel, Th. F., Monod, A., Prévôt, A. S. H., Seinfeld, J. H., Surratt, J. D., Szmigielski, R., and Wildt, J.: The formation, properties and impact of secondary organic aerosol: current and emerging issues, Atmos. Chem. Phys., 9, 5155-5236, doi:10.5194/acp-9-51552009, 2009.

Herckes, P., Valsaraj, K. T., and Collett Jr., J. L.: A review of observations of organic matter in fogs and clouds: Origin, processing and fate, Atmos. Res., 132-133, 434-449, doi:10.1016/j.atmosres.2013.06.005, 2013.

Hering, S. V. and Friedlander, S. K.: Origins of aerosol sulfur size distributions in the Los Angeles basin, Atmos. Environ., 16, 2647-2656, 1982.

Herrmann, H.: Kinetics of Aqueous Phase Reactions Relevant for Atmospheric Chemistry, Chem. Rev., 103, 4691-4716, 2003.

Herrmann, H., Schaefer, T., Tilgner, A., Styler, S. A., Weller, C., Teich, M., and Otto, T.: Tropospheric Aqueous-Phase Chemistry: Kinetics, Mechanisms, and Its Coupling to a Changing Gas Phase, Chem. Rev., 115, 4259-4334, 2015.

Hilal, S. H., Ayyampalayam, S. N., and Carreira, L. A.: Air-Liquid Partition Coefficient for a Diverse Set of Organic Compounds: Henry's Law Constant in Water and Hexadecane, Environ. Sci. Technol., 42, 9231-9236, 2008.

Hu, K. S., Darer, A. I., and Elrod, M. J.: Thermodynamics and kinetics of the hydrolysis of atmospherically relevant organonitrates and organosulfates, Atmos. Chem. Phys., 11, 8307-8320, doi:10.5194/acp-11-8307-2011, 2011.

Huang, X.-F., Yu, J. Z., He, L.-Y., and Yuan, Z.: Water-soluble organic carbon and oxalate in aerosols at a coastal urban site in China: Size distribution characteristics, sources, and formation mechanisms, J. Geophys. Res.-Atmos., 111, D22212, doi:10.1029/2006JD007408, 2006.

IPCC: Climate Change 2013: The Physical Science Basis. Contribution of Working Group I to the Fifth Assessment Report of the Intergovernmental Panel on Climate Change, edited by: Stocker, T. F., Qin, D., Plattner, G.-K., Tignor, M., Allen, S. K., Boschung, J., Nauels, A., Xia, Y., Bex, V., and Midgley, P. M., Cambridge, United Kingdom and New York, NY, USA, 2013.

John, W., Wall, S. M., Ondo, J. L., and Winklmayr, W.: Modes in the size distributions of atmospheric inorganic aerosol, Atmos. Environ., 24, 2349-2359, 1990.

Kanakidou, M., Seinfeld, J. H., Pandis, S. N., Barnes, I., Dentener, F. J., Facchini, M. C., Van Dingenen, R., Ervens, B., Nenes, A., Nielsen, C. J., Swietlicki, E., Putaud, J. P., Balkanski, Y., Fuzzi, S., Horth, J., Moortgat, G. K., Winterhalter, R., Myhre, C. E. L., Tsigaridis, K., Vignati, E., Stephanou, E. G., and Wilson, J.: Organic aerosol and global climate modelling: a review, Atmos. Chem. Phys., 5, 1053-1123, doi:10.5194/acp-5-1053-2005, 2005.
Kleindienst, T. E., Edney, E. O., Lewandowski, M., Offenberg, J. H., and Jaoui, M.: Secondary organic carbon and aerosol yields from the irradiations of isoprene and alpha-pinene in the presence of NOx and SO2, Environ. Sci. Technol., 40, 3807-3812, 2006.

Kroll, J. H., Ng, N. L., Murphy, S. M., Flagan, R. C., and Seinfeld, J. H.: Secondary organic aerosol formation from isoprene photooxidation under high-NOx conditions, Geophys. Res. Lett., 32, L18808, doi:10.1029/2005GL023637, 2005.

Kuwata, M., Zorn, S. R., and Martin, S. T.: Using Elemental Ratios to Predict the Density of Organic Material Composed of Carbon, Hydrogen, and Oxygen, Environ. Sci. Technol., 46, 787794, 2012.

Lee, A. K. Y., Hayden, K. L., Herckes, P., Leaitch, W. R., Liggio, J., Macdonald, A. M., and Abbatt, J. P. D.: Characterization of aerosol and cloud water at a mountain site during WACS 2010: secondary organic aerosol formation through oxidative cloud processing, Atmos. Chem. Phys., 12, 7103-7116, doi:10.5194/acp-12-7103-2012, 2012.

Leng, C., Kish, J. D., Kelley, J., Mach, M., Hiltner, J., Zhang, Y., and Liu, Y.: Temperature-Dependent Henry's Law Constants of Atmospheric Organics of Biogenic Origin, J. Phys. Chem. A, 117, 10359-10367, 2013.

Lim, Y. B., Tan, Y., and Turpin, B. J.: Chemical insights, explicit chemistry, and yields of secondary organic aerosol from $\mathrm{OH}$ radical oxidation of methylglyoxal and glyoxal in the aqueous phase, Atmos. Chem. Phys., 13, 8651-8667, doi:10.5194/acp-13-86512013, 2013.

Lin, P., Huang, X.-F., He, L.-Y., and Yu, J. Z.: Abundance and size distribution of HULIS in ambient aerosols at a rural site in South China, J. Aerosol Sci., 41, 74-87, 2010.

Liu, Y., Monod, A., Tritscher, T., Praplan, A. P., DeCarlo, P. F., Temime-Roussel, B., Quivet, E., Marchand, N., Dommen, J., and Baltensperger, U.: Aqueous phase processing of secondary organic aerosol from isoprene photooxidation, Atmos. Chem. Phys., 12, 5879-5895, doi:10.5194/acp-12-5879-2012, $2012 \mathrm{a}$.

Liu, Y., Siekmann, F., Renard, P., El Zein, A., Salque, G., El Haddad, I., Temime-Roussel, B., Voisin, D., Thissen, R., and Monod, A.: Oligomer and SOA formation through aqueous phase photooxidation of methacrolein and methyl vinyl ketone, Atmos. Environ., 49, 123-129, 2012b.

Loza, C. L., Chan, A. W. H., Galloway, M. M., Keutsch, F. N., Flagan, R. C., and Seinfeld, J. H.: Characterization of Vapor Wall Loss in Laboratory Chambers, Environ. Sci. Technol., 44, 5074 5078, 2010.

Matsunaga, A. and Ziemann, P. J.: Gas-Wall Partitioning of Organic Compounds in a Teflon Film Chamber and Potential Effects on Reaction Product and Aerosol Yield Measurements, Aerosol Sci. Technol., 44, 881-892, 2010.

Meng, Z. and Seinfeld, J. H.: On the Source of the Submicrometer Droplet Mode of Urban and Regional Aerosols, Aerosol Sci. Technol., 20, 253-265, 1994.

Michoud, V., Colomb, A., Borbon, A., Miet, K., Beekmann, M., Camredon, M., Aumont, B., Perrier, S., Zapf, P., Siour, G., AitHelal, W., Afif, C., Kukui, A., Furger, M., Dupont, J. C., Haeffelin, M., and Doussin, J. F.: Study of the unknown HONO daytime source at a European suburban site during the MEGAPOLI summer and winter field campaigns, Atmos. Chem. Phys., 14, 2805-2822, doi:10.5194/acp-14-2805-2014, 2014. 
Middlebrook, A. M., Bahreini, R., Jimenez, J. L., and Canagaratna, M. R.: Evaluation of Composition-Dependent Collection Efficiencies for the Aerodyne Aerosol Mass Spectrometer using Field Data, Aerosol Sci. Technol., 46, 258-271, 2012.

Nguyen, T. B., Laskin, A., Laskin, J., and Nizkorodov, S. A.: Direct aqueous photochemistry of isoprene high-NOx secondary organic aerosol, Phys. Chem. Chem. Phys., 14, 9702-9714, 2012.

Ortiz-Montalvo, D. L., Lim, Y. B., Perri, M. J., Seitzinger, S. P., and Turpin, B. J.: Volatility and Yield of Glycolaldehyde SOA Formed through Aqueous Photochemistry and Droplet Evaporation, Aerosol Sci. Technol., 46, 1002-1014, 2012.

Peltier, R. E., Hecobian, A. H., Weber, R. J., Stohl, A., Atlas, E. L., Riemer, D. D., Blake, D. R., Apel, E., Campos, T., and Karl, T.: Investigating the sources and atmospheric processing of fine particles from Asia and the Northwestern United States measured during INTEX B, Atmos. Chem. Phys., 8, 1835-1853, doi:10.5194/acp-8-1835-2008, 2008.

Perri, M. J., Seitzinger, S., and Turpin, B. J.: Secondary organic aerosol production from aqueous photooxidation of glycolaldehyde: Laboratory experiments, Atmos. Environ., 43, 1487-1497, 2009.

Perring, A. E., Pusede, S. E., and Cohen, R. C.: An Observational Perspective on the Atmospheric Impacts of Alkyl and Multifunctional Nitrates on Ozone and Secondary Organic Aerosol, Chemical Reviews, 113, 5848-5870, 2013.

Poulain, L., Katrib, Y., Isikli, E., Liu, Y., Wortham, H., Mirabel, P., Le Calve, S., and Monod, A.: In-cloud multiphase behaviour of acetone in the troposphere: Gas uptake, Henry's law equilibrium and aqueous phase photooxidation, Chemosphere, 81, 312-320, 2010.

Raventos-Duran, T., Camredon, M., Valorso, R., Mouchel-Vallon, C., and Aumont, B.: Structure-activity relationships to estimate the effective Henry's law constants of organics of atmospheric interest, Atmos. Chem. Phys., 10, 7643-7654, doi:10.5194/acp10-7643-2010, 2010.

Reed Harris, A. E., Ervens, B., Shoemaker, R. K., Kroll, J. A., Rapf, R. J., Griffith, E. C., Monod, A., and Vaida, V.: Photochemical Kinetics of Pyruvic Acid in Aqueous Solution, J. Phys. Chem. A, 118, 8505-8516, 2014.

Rindelaub, J. D., McAvey, K. M., and Shepson, P. B.: The photochemical production of organic nitrates from $\alpha$-pinene and loss via acid-dependent particle phase hydrolysis, Atmos. Environ.t, 100, 193-201, 2015.

Schwartz, S. E.: Mass-transport considerations pertinent to aqueous-phase reactions of gases in liquid-water clouds, in: Chemistry of Multiphase Atmospheric Systems, edited by: Jaeschke, W., NATO ASI Series, Springer, Berlin, Heidelberg, Germany, 1986.

Staudinger, J. and Roberts, P. V.: A critical review of Henry's law constants for environmental applications, Crit. Rev. Env. Sci. Tec., 26, 205-297, 1996.

Staudinger, J. and Roberts, P. V.: A critical compilation of Henry's law constant temperature dependence relations for organic compounds in dilute aqueous solutions, Chemosphere, 44, 561-576, 2001.
Stubenrauch, C. J., Rossow, W. B., Kinne, S., Ackerman, S., Cesana, G., Chepfer, H., Di Girolamo, L., Getzewich, B., Guignard, A., Heidinger, A., Maddux, B. C., Menzel, W. P., Minnis, P., Pearl, C., Platnick, S., Poulsen, C., Riedi, J., Sun-Mack, S., Walther, A., Winker, D., Zeng, S., and Zhao, G.: Assessment of Global Cloud Datasets from Satellites: Project and Database Initiated by the GEWEX Radiation Panel, B. Am. Meteorol. Soc., 94, 1031-1049, 2013.

Tan, Y., Lim, Y. B., Altieri, K. E., Seitzinger, S. P., and Turpin, B. J.: Mechanisms leading to oligomers and SOA through aqueous photooxidation: insights from $\mathrm{OH}$ radical oxidation of acetic acid and methylglyoxal, Atmos. Chem. Phys., 12, 801-813, doi:10.5194/acp-12-801-2012, 2012.

Wang, J., Doussin, J. F., Perrier, S., Perraudin, E., Katrib, Y., Pangui, E., and Picquet-Varrault, B.: Design of a new multi-phase experimental simulation chamber for atmospheric photosmog, aerosol and cloud chemistry research, Atmos. Meas. Tech., 4, 2465-2494, doi:10.5194/amt-4-2465-2011, 2011.

Warneke, C., Veres, P., Holloway, J. S., Stutz, J., Tsai, C., Alvarez, S., Rappenglueck, B., Fehsenfeld, F. C., Graus, M., Gilman, J. B., and de Gouw, J. A.: Airborne formaldehyde measurements using PTR-MS: calibration, humidity dependence, intercomparison and initial results, Atmos. Meas. Tech., 4, 23452358, doi:10.5194/amt-4-2345-2011, 2011.

Wylie, D., Jackson, D. L., Menzel, W. P., and Bates, J. J.: Trends in Global Cloud Cover in Two Decades of HIRS Observations, J. Climate, 18, 3021-3031, 2005.

Zhang, H., Surratt, J. D., Lin, Y. H., Bapat, J., and Kamens, R. M.: Effect of relative humidity on SOA formation from isoprene/NO photooxidation: enhancement of 2-methylglyceric acid and its corresponding oligoesters under dry conditions, Atmos. Chem. Phys., 11, 6411-6424, doi:10.5194/acp-11-6411-2011, 2011.

Zhang, Q., Jimenez, J. L., Canagaratna, M. R., Allan, J. D., Coe, H., Ulbrich, I., Alfarra, M. R., Takami, A., Middlebrook, A. M., Sun, Y. L., Dzepina, K., Dunlea, E., Docherty, K., DeCarlo, P. F., Salcedo, D., Onasch, T., Jayne, J. T., Miyoshi, T., Shimono, A., Hatakeyama, S., Takegawa, N., Kondo, Y., Schneider, J., Drewnick, F., Borrmann, S., Weimer, S., Demerjian, K., Williams, P., Bower, K., Bahreini, R., Cottrell, L., Griffin, R. J., Rautiainen, J., Sun, J. Y., Zhang, Y. M., and Worsnop, D. R.: Ubiquity and dominance of oxygenated species in organic aerosols in anthropogenically-influenced Northern Hemisphere midlatitudes, Geophys. Res. Lett., 34, L13801, doi:10.1029/2007GL029979, 2007.

Zhang, X., Cappa, C. D., Jathar, S. H., McVay, R. C., Ensberg, J. J., Kleeman, M. J., and Seinfeld, J. H.: Influence of vapor wall loss in laboratory chambers on yields of secondary organic aerosol, Proc. Natl. Acad. Sci. USA, 111, 5802-5807, 2014.

Zhou, X., Huang, G., Civerolo, K., and Schwab, J.: Measurement of Atmospheric Hydroxyacetone, Glycolaldehyde, and Formaldehyde, Environ. Sci. Technol., 43, 2753-2759, 2009.

Zhou, X. L., Qiao, H. C., Deng, G. H., and Civerolo, K.: A method for the measurement of atmospheric HONO based on DNPH derivatization and HPLC analysis, Environ. Sci. Technol., 33, 3672-3679, 1999. 